\title{
EFFECT OF FOLIAR SPRAY WITH UREA AND DRY YEAST EXTRACT ON HEAD LETTUCE PRODUCTION
}

\author{
A. A. Abd El Galil ; Abou El Salehein E. H. and M. M. El Hamady \\ Plant Production Department, Faculty of Technological \& Development, \\ Zagazig University, Egypt. \\ e.mail: eelsalehein@yahoo.co.uk
}

\section{ABSTRACT}

The present investigation was carried out during the two successive seasons of 2018/2019 and 2019/2020 at Abo El-Matameer, Behairah Governorate, Egypt to study the effect of seven treatments a foliar application, i.e. control (spray with water only), dry yeast at $2 \mathrm{~g} / \mathrm{L}$, dry yeast at $4 \mathrm{~g} / \mathrm{L}$, urea at $0.5 \%$, urea at $1.0 \%$, urea at $1.5 \%$, and urea at $2 \%$ on growth, yield and chemical content of lettuce plants.

The experiment was arranged in a randomized complete blocks design in three replications.

The obtained results are summarized as follows:

Using urea and dry yeast extract levels as a foliar spray on vegetative growth characters, i.e. root length, head length, number of leaves/head, length and width of leaf, diameter of head, fresh and dry weight of head, pigments content, chemical contents and head yield of lettuce and its components were significantly increased compared to the control treatment. The highest values of these characters of lettuce were recorded by using $1 \%$ urea, in both growing seasons. This treatment was followed by the treatments of dry yeast extract at $4 \mathrm{~g} / \mathrm{L}$, dry yeast extract at $2 \mathrm{~g} / \mathrm{L}$, and urea at $0.5 \%$, respectively.

Conclusively: It can be concluded that the treatment of $1 \%$ urea gave the best results on all characters of head lettuce.

Key words: Head lettuce - foliar spray with urea and dry yeast extract

\section{INTRODUCTION:}

Head lettuce (Lactuce sativa L.) is the world's most used salad crop. It is one the important leafy vegetable crops which are eaten fresh and is a major and extensively grown cool season vegetable best adapted to temperate locations (Rubatzky and Tamaguchi, 1997). It is taken as synonym of salads and contains about $6-19 \%$ mineral elements on the dry weight basis. It is 
the richest source of calcium among other vegetables and is the second richest source of minerals after spinach.

The milky liquid substance, latex present in lettuce contains Lactucin and lactucopicrin, which helps to regulate nervous system, improves sleepiness, appetite and digestion and reduces high blood pressure, lowers high cholesterol levels, lower inflammation and provides a supply of antioxidants (Sharma, 2005 and Masarirambi et al., 2012). It is contains a lot of cellulose, which is highty important and required for human health and it facilitates digestion (Chaudhury, 1967).

Plants, need all nutrients in different ratios for their germination, growth and development stages, and get them from soil, water or air by their roots or leaves. Some of these nutrients require in a large amounts, whereas, others are less quantities. Nutrients such as nitrogen is an important nutrient and contribute to increase yield and plant nutrition (Wang et al., 2008). Nitrogen is the most important essential macronutrient for production of leafy vegetables, required by plants in the largest proportion (Broadley et al., 2000).

Foliar application is one of the techniques of fertilization. Nutrients can be effectively taken up by plants when they are used as foliar fertilizer. Different studies have been done on foliar application of vegetable crops. The response to foliar application of urea as $\mathrm{N}$ source has been reported in lettuce, that increased vegetative growth and yield, as well as decreased $\mathrm{No}_{3}$ level in leaves (Wojciechowska, 2004 and Yucel et al., 2013).

Bio-stimulants are biologically active compounds that enhance metabolism and promote plant development when applied in small quantities. Bio-stimulants contain microelements, hormones, enzymes, proteins, vitamins, amino acids, and other compounds (Edmeades, 2002). It is an environmental friendly method for improving plant development that reduces fertilizer and pesticide consumption and optaining high yield of nutritionally valuable vegetables (Paradikovic et al., 2011).

Dry yeast is a natural bio-substance suggested to be useful stimulatory, nutritional and protective functions. Many investigators cleared out that application of dry yeast as foliar spray was found to increase growth, yield and quality of some vegetable crops (Fathy and Farid, 2000, and Abou El. Nasr et al., 2001, Mona et al., 2005 and Fawzy, 2010 a \& b).

This work was carried out to study the effect of urea and dry yeast as foliar spray on growth, yield and chemical content of head lettuce plants. 


\section{MATERIALS AND METHODS}

The present investigation was carried out during the two successive seasons of 2018/2019 and 2019/2020 at Abo El-Matameer, Behairah Governorate, Egypt to study the effect of seven treatments of foliar application, i.e. control (spray with water only), dry yeast at $2 \mathrm{~g} / \mathrm{L}$, dry yeast at $4 \mathrm{~g} / \mathrm{L}$, urea at $0.5 \%, 1.0 \%, 1.5 \%$, and $2 \%$ on growth, yield and chemical content of lettuce plants.

Seeds of head lettuce (Lactuca sativa L.) cv. Lymar (9283) were drilled in foam trays of 209 holes in a media consisting of peat moss and vermiculate 1:1 trays were wetted and warmed under plastic sheet for three days, then kept under plastic tunel. Normal nursery treatments were followed till seedlings become suitable for transplanting. The time of transplanting took place after one month at $11^{\text {th }}$ and $15^{\text {th }}$ of November in both growing seasons of the experiment, respectively. The seeds of head lettuce was sown in 10 of November in both growing seasons in foam trays .

Plants were sprayed with dry yeast extract and urea 6 weeks after transplanting four times every week intervals. Pest control and other agriculture practices, i.e. cultivation irrigation and fertilization with phosphorus ( calcium super phosphate,16.6 P2O5, $200 \mathrm{~kg} /$ feddan) , and potassium ( potassium chloride ,48\% K2 O, 100kg/feddan) were applied wherever it was necessary and as commonly recommended in the commercial head lettuce production. Harvesting time was carried out 81 and 87 days after transplanting in the first and second seasons, respectively. The experiment was arranged in a complete randomized blocks design in three replications.

\section{Data recorded:}

Five plants of each plot were randomly chosen at 75 days after transplanting and the following data were recorded:

\section{a) Vegetative growth parameters:}

1 .Root length $(\mathrm{cm})$

2. Head height $(\mathrm{cm})$.

3. Number of leaves.

4. Leaf length $(\mathrm{cm})$.

5. Leaf width $(\mathrm{cm})$.

6. Fresh weight of plant $(\mathrm{g})$

7. Dry weight of plant $(\mathrm{g})$. 
b) Yield:

1. Diameter of head $(\mathrm{cm})$

2. Average head weight (g)

c) Pigments content:

1. Chlorophyll a

2. Chlorophyll b

3. Total chlorophyll $(\mathrm{a}+\mathrm{b})$

4. Total carotenoids

\section{d) Chemical content:}

At harvesting time, three samples of heads were randomly taken at the second season, Nitrate $-\mathrm{N}$ content in the fresh head lettuce leaves were determined using the method described by A. O. A. C. (2000).

. Samples of leaves were oven dried at $70^{\circ} \mathrm{c}$ then fine grounded and wet digested, total nitrogen, phosphorus and potassium concentration in leaves were determined according to the methods described by A. O. A. C. (2000).

\section{Statistical analysis:}

The obtained data were subjected to the statistical analysis according to the method of Snedecor and Cochran (1980). The treatments means were compared by used SAS program (SAS, 2004).

\section{RESULTS AND DISCUSSION}

\section{Vegetative growth parameters:}

Data in Tables (1-2) show clearly that using urea and dry yeast extract levels as a foliar spray on vegetative growth characters, i.e. root length , head length, number of leaves/ head, length and width of leaf, diameter of head, and fresh and dry weight of plant were increased of these vegetative growth characters of lettuce plants compared with the control treatment. The highest values of vegetative growth characters of head lettuce were recorded by using $1 \%$ urea, in both growing seasons. This treatment was followed by the treatments of dry yeast extract at $4 \mathrm{~g} / \mathrm{L}$, dry yeast extract at $2 \mathrm{~g} / \mathrm{L}$ and urea at $0.5 \%$, respectively. There are no differences between urea at $1.5 \%$ and $2.0 \%$. On the contrary, the lowest value of all the vegetative growth characters of head lettuce was found in case of the control treatment. These findings were true in both growing seasons. 
Regarding the effect of urea as a source of nitrogen where it's a vital role on plants, Edmond et al. (1981) illustrated that nitrogen is an indispensable elementary constituent of numerous organic compounds of general importance (amino acids, protein, nucleic acids) and it is needed in the formation of protoplasm and new cells, consequently increased the number of leaves and in chancing the biosynthesis in plant. Moreover, Broadley et al. (2000) demonstrated that nitrogen is the most important essential macronutrient for production of leafy vegetables, it required by plants in the largest proportion when applied at the soil while, it was lowest quantities when applied as foliar application.

Respecting the role of dry yeast extract in plants, Ahmed et al. (1997) and Abou El. Nasr et al. (2001) stated that the positive effect of applying active dry yeast was attributed to its own content of different nutrients, high percentage of protein, large amounts of vitamin B and natural growth regulators such as cytokinins. In addition, Amer (2004) noticed that yeast extract is a natural bio-substance used as foliar application, it is contain high levels of nutrient elements and existence of stimulative growth regulators compounds like auxins, gibberllins, and cytokinins that stimulates cell division and enlargement, as well as, the synthesis of protein, nucleic acid and chlorophyll.

The obtained results are in accordance with these mentioned by Guvenc et al. (2006), Yildirim et al. (2007). Younis et al. (2008), Wojciechowska and Kowalska (2011), Yucel et al. (2013) and Abdel-salam (2018), who working on different organic manure. As well as, Fawzy (2010a and b), Saleh et al. (2010), Shehata et al. (2012), Marzauk et al. (2014), Farrag et al (2016), Fouda and Abd- El hamid (2017) and Alsaady et al. (2020), who working on yeast. All researchers concluded that organic manure or dry yeast extract were significantly increased vegetative growth parameters of legumes plants.

\section{Head yield and its components:}

Data in Tables (3 and 4) indicated that all treatment of urea and dry yeast extract levels had a significantly effect on head yield of lettuce plants, i.e. average weight of head, three head weight $(\mathrm{kg})$ and ten head weight $(\mathrm{kg})$, as well as, head quality, i. e. leaf length width and head diameter. The treatment of $1 \%$ urea appeared superiority in fresh yield of head lettuce and quality, followed by the treatment of dry yeast extract at the level of $4 \mathrm{~g} / \mathrm{L}$. 
On the other hand, the lowest values of head yield and quality of head lettuce were recorded as a result from the control treatment.

The increase in fresh weight of head lettuce and its components as a result of urea and dry yeast extract might be attributed to the increase in its vegetative growth and dry matter accumulation (Tables, 1 and 2), pigments

Table (1): Effect of foliar spray with urea fertilizer levels and dry yeast extract on vegetative growth of lettuce plant during 2018 /2019 and 2019/2020 seasons

\begin{tabular}{|c|c|c|c|c|c|c|}
\hline \multirow[t]{2}{*}{ Treatments } & \multicolumn{2}{|c|}{ Root length (cm) } & \multicolumn{2}{|c|}{$\begin{array}{l}\text { Head height } \\
\text { (cm) }\end{array}$} & \multicolumn{2}{|c|}{ Number of leaves } \\
\hline & $\begin{array}{c}2018 \\
\text { season }\end{array}$ & $\begin{array}{c}2019 \\
\text { season }\end{array}$ & $\begin{array}{c}2018 \\
\text { season }\end{array}$ & $\begin{array}{c}2019 \\
\text { season }\end{array}$ & $\begin{array}{c}2018 \\
\text { season }\end{array}$ & $\begin{array}{c}2019 \\
\text { season }\end{array}$ \\
\hline Control & 3.1 & 9.33 & 13.61 & 21.66 & 29.66 & 23.00 \\
\hline $\begin{array}{l}\text { Dry yeast at } \\
2 \mathrm{~g} / \mathrm{L}\end{array}$ & 4.66 & 13.00 & 14.00 & 22.33 & 27.66 & 25.33 \\
\hline $\begin{array}{l}\text { Dry yeast at } 4 \\
\mathrm{~g} / \mathrm{L}\end{array}$ & 5.00 & 13.00 & 14.00 & 23.33 & 25.00 & 26.00 \\
\hline Urea at $0.5 \%$ & 4.33 & 11.33 & 14.00 & 21.00 & 23.00 & 23.00 \\
\hline Urea at $1.0 \%$ & 5.33 & 15.33 & 14.66 & 24.66 & 38.00 & 26.33 \\
\hline Urea at $1.5 \%$ & 3.66 & 12.00 & 14.33 & 21.33 & 24.00 & 24.33 \\
\hline Urea at $2 \%$ & 3.00 & 10.00 & 13.66 & 21.66 & 23.66 & 24.33 \\
\hline LSD ( $5 \%)$ & 0.43 & 1.23 & 0.28 & 5.08 & 5.67 & 4.68 \\
\hline
\end{tabular}

Table (2): Effect of foliar spray with urea fertilizer levels and dry yeast extract on fresh and dry weight of lettuce plant during 2018/2019 and 2019/2020 seasons

\begin{tabular}{|c|c|c|c|c|}
\hline \multirow[t]{2}{*}{ Treatments } & \multicolumn{2}{|c|}{ Plant fresh weight $(\mathrm{g})$} & \multicolumn{2}{|c|}{ Plant dry weight (g) } \\
\hline & $\begin{array}{l}2018 \\
\text { season }\end{array}$ & \begin{tabular}{|l|}
2019 \\
season \\
\end{tabular} & \begin{tabular}{|l|}
2018 \\
season \\
\end{tabular} & $\begin{array}{l}2019 \\
\text { season } \\
\end{array}$ \\
\hline Control & 575.1 & 686.00 & \begin{tabular}{|l|}
25.41 \\
\end{tabular} & 26.23 \\
\hline Dry yeast at $2 \mathrm{~g} / \mathrm{L}$ & 741.5 & 674.30 & 25.91 & 26.93 \\
\hline Dry yeast at $4 \mathrm{~g} / \mathrm{L}$ & 881.7 & 697.70 & 34.11 & 33.33 \\
\hline Urea at $0.5 \%$ & 847.1 & 843.70 & 32.75 & 33.00 \\
\hline Urea at $1.0 \%$ & 891.1 & 899.70 & 34.15 & 33.33 \\
\hline Urea at $1.5 \%$ & 698.9 & 748.30 & 28.30 & 29.33 \\
\hline Urea at $2 \%$ & 663.2 & 892.30 & 28.17 & 29.00 \\
\hline
\end{tabular}




\begin{tabular}{|l|l|l|l|l|}
\hline LSD ( 5 \%) & 5.7 & 8.68 & 0.71 & 0.49 \\
\hline
\end{tabular}

contents, (Tables 5 and 6), chemical content (Table, 7) and then increased the fresh head yield and its components.

These results are in concurrence with those listed by Guvenc et al. (2006), Yildirim et al. (2007), Abdel-Salam (2018), and Ghimire et al.

Table (3): Effect of foliar spray with urea fertilizer levels and dry yeast extract on head yield of lettuce plant during 2018/2019 and 2019/2020 seasons

\begin{tabular}{|l|l|l|l|l|l|l|}
\hline \multirow{2}{*}{ Treatments } & \multicolumn{2}{|c|}{$\begin{array}{c}\text { Head weight } \\
\text { (g) }\end{array}$} & \multicolumn{2}{c|}{$\begin{array}{c}\text { Three head } \\
\text { weight }(\mathbf{g})\end{array}$} & \multicolumn{2}{c|}{$\begin{array}{c}\text { Ten head weight } \\
\text { (g) }\end{array}$} \\
\cline { 2 - 7 } & $\begin{array}{l}\mathbf{2 0 1 8} \\
\text { season }\end{array}$ & $\begin{array}{l}\mathbf{2 0 1 9} \\
\text { season }\end{array}$ & $\begin{array}{l}\mathbf{2 0 1 8} \\
\text { season }\end{array}$ & $\begin{array}{l}\mathbf{2 0 1 9} \\
\text { season }\end{array}$ & $\begin{array}{l}\mathbf{2 0 1 8} \\
\text { season }\end{array}$ & $\begin{array}{l}\mathbf{2 0 1 9} \\
\text { season }\end{array}$ \\
\hline Control & 0.70 & 0.90 & 2.10 & 2.25 & 7.44 & 7.50 \\
\hline Dry yeast at 2g/L & 0.89 & 0.85 & 2.69 & 2.65 & 7.76 & 8.83 \\
\hline Dry yeast at 4 g/L & 0.96 & 0.88 & 2.89 & 2.70 & 8.77 & 9.00 \\
\hline Urea at 0.5\% & 0.72 & 0.83 & 2.56 & 2.35 & 8.41 & 8.33 \\
\hline Urea at 1.0\% & 1.12 & 0.91 & 3.37 & 2.75 & 9.25 & 9.16 \\
\hline Urea at 1.5\% & 0.85 & 0.78 & 2.18 & 2.55 & 8.71 & 8.50 \\
\hline Urea at 2\% & 0.70 & 0.75 & 2.12 & 2.50 & 8.30 & 7.80 \\
\hline LSD (5\%) & $\mathbf{0 . 1 8}$ & $\mathbf{0 . 1 3}$ & $\mathbf{0 . 2 4}$ & $\mathbf{0 . 0 9}$ & $\mathbf{0 . 1 0}$ & $\mathbf{0 . 1 2}$ \\
\hline
\end{tabular}

Table ( 4 ): Effect of foliar spray with urea fertilizer levels and dry yeast extract on yield quality of lettuce plant during 2018/2019 and 2019/2020 seasons

\begin{tabular}{|c|c|c|c|c|c|c|}
\hline \multirow[t]{2}{*}{ Treatments } & \multicolumn{2}{|c|}{$\begin{array}{c}\text { Leaf length } \\
(\mathrm{cm})\end{array}$} & \multicolumn{2}{|c|}{$\begin{array}{c}\text { Leaf width } \\
(\mathrm{cm})\end{array}$} & \multicolumn{2}{|c|}{$\begin{array}{c}\text { Head diameter } \\
(\mathrm{cm})\end{array}$} \\
\hline & $\begin{array}{l}2018 \\
\text { season }\end{array}$ & $\begin{array}{l}2019 \\
\text { season }\end{array}$ & $\begin{array}{l}2018 \\
\text { season }\end{array}$ & $\begin{array}{l}2019 \\
\text { season }\end{array}$ & $\begin{array}{l}2018 \\
\text { season }\end{array}$ & $\begin{array}{l}2019 \\
\text { season }\end{array}$ \\
\hline Control & 25.66 & 27.00 & 24.00 & 23.00 & 22.00 & 25.33 \\
\hline Dry yeast at $2 \mathrm{~g} / \mathrm{L}$ & 27.66 & 28.00 & 27.66 & 25.33 & 24.33 & 29.00 \\
\hline Dry yeast at $4 \mathrm{~g} / \mathrm{L}$ & 28.33 & 29.33 & 29.00 & 26.00 & 24.66 & 30.33 \\
\hline Urea at $0.5 \%$ & 27.66 & 29.33 & 27.33 & 23.00 & 24.33 & 26.33 \\
\hline Urea at $1.0 \%$ & 29.33 & 30.66 & 29.33 & 26.33 & 25.66 & 31.33 \\
\hline Urea at $1.5 \%$ & 25.66 & 28.00 & 27.66 & 24.33 & 24.00 & 26.33 \\
\hline Urea at $2 \%$ & 27.33 & 27.66 & 24.33 & 24.33 & 23.33 & 25.66 \\
\hline LSD ( $5 \%)$ & 1.61 & 1.33 & 1.02 & 1.08 & 0.12 & 0.17 \\
\hline
\end{tabular}


(2019) who working with urea as foliar spray on lettuce plants, as well as, Fawzy (2010a), Farrag et al. (2016), and Kanimarani (2020) who working with foliar dry yeast extract on lettuce plants.

They concluded that foliar spray with urea or dry yeast extract significantly increased the productivity of lettuce plants.

\section{Leaves pigments content:}

Data in Tables (5-6) indicated that all the studied treatments had different significant effect on leaves pigments content of head lettuce, i.e chlorophyll $\mathrm{a}$, chlorophyll $\mathrm{b}$, total chlorophyll $(\mathrm{a}+\mathrm{b})$ and carotenoids.

The foliar application of $1 \%$ urea and dry yeast extract at the level of 4 $\mathrm{g} / \mathrm{L}$, being the most effective treatments on the values of pigments content of head lettuce. These treatments were followed by the treatments of dry yeast extract at $2 \mathrm{~g} / \mathrm{L}$, and urea at $0.5 \%$ on pigments content. These results are true in both growing seasons.

In this respect, as the important role of urea as a source of nitrogen and dry yeast in leafy vegetables, Ivanova and vassilev (2003) illustrated that the influence of $\mathrm{N}$ on plant growth and development, as well as, photothynthetic pigments is often connected with the process of photosynthesis, because the suitable quantity of $\mathrm{N}$ in the medium degree (1\%), determines the formation and the functional state assimilation apparatus of plants including the content of photosynthetic pigments, the synthesis of the enzymes taking part in the carbon reduction and the formation of the membrane system of chloroplasts. Regarding the important role of dry yeast, Taha et al. (2016) concluded that the enhancement effect of yeast extract might be attributed to its influence on metabolism, biological activity, photosynthetic pigments and enzyme activity which in turn encourage vegetative growth and increasing the photosynthetic pigments. Similar trends were also registered by Younis et al. (2008), who found that urea as foliar spray on lettuce plants caused an increases in pigments content.

Moreover, El-Sherbeny et al. (2007), Saleh et al. (2010), Abbas (2013), Fouda et al. (2017) and Alsaady et al. (2020), who sprayed plants with yeast extracts showed that yeast extract significantly increased the pigments content of plants.

\section{$N, P$ and $K$ contents and accumulation of nitrate:}


Data in Table (7) revealed that the studied treatments of urea levels and dry yeast extracts caused a significantly different in chemical contents of head lettuce leaves and the nitrate accumulation. The suitable urea as foliar spray, i.e. $1 \%$ recorded a highest values on $\mathrm{N}, \mathrm{P}$ and $\mathrm{K}$ contents of leaves, and medium level of nitrate accumulation, as well as, dry yeast extract at the level of $4 \mathrm{~g} / \mathrm{L}$ gave the highest values on $\mathrm{N}, \mathrm{P}$ and $\mathrm{K}$ content in head lettuce leaves and suitable level of nitrate with any harmful to human race. These results were followed by dry yeast extract at the rate of $2 \mathrm{~g} / \mathrm{L}$, and $0.5 \%$ urea, respectively.

Table (5): Effect of foliar spray with urea fertilizer levels and dry yeast extract on pigments content; chlorophyll A and chlorophyll B (mg/g f. w. )

\begin{tabular}{|c|c|c|c|c|}
\hline \multirow[t]{2}{*}{ Treatments } & \multicolumn{2}{|c|}{ Chlorophyll (A) } & \multicolumn{2}{|c|}{ Chlorophyll (B) } \\
\hline & $\begin{array}{c}2018 \\
\text { season }\end{array}$ & 2019 season & 2018 season & $\begin{array}{c}2019 \\
\text { season }\end{array}$ \\
\hline Control & 0.05 & 0.19 & 0.02 & 0.35 \\
\hline Dry yeast at $2 \mathrm{~g} / \mathrm{L}$ & 0.03 & 0.21 & 0.04 & 0.42 \\
\hline Dry yeast at $4 \mathrm{~g} / \mathrm{L}$ & 0.04 & 0.17 & 0.04 & 0.30 \\
\hline Urea at $0.5 \%$ & 0.03 & 0.26 & 0.01 & 0.35 \\
\hline Urea at $1.0 \%$ & 0.07 & 0.25 & 0.04 & 0.45 \\
\hline Urea at $1.5 \%$ & 0.03 & 0.24 & 0.03 & 0.36 \\
\hline Urea at $2 \%$ & 0.01 & 0.25 & 0.03 & 0.44 \\
\hline LSD ( $5 \%$ ) & 0.01 & 0.02 & 0.01 & 0.03 \\
\hline
\end{tabular}

Table (6): Effect of foliar spray with urea fertilizer levels and dry yeast extract on total chlorophyll $(\mathrm{A}+\mathrm{B})$ and carotenoids

\begin{tabular}{|l|c|c|c|c|}
\hline \multirow{2}{*}{ Treatments } & \multicolumn{2}{|c|}{$\begin{array}{c}\text { Total Chlorophyll } \\
(\mathbf{A + B})\end{array}$} & \multicolumn{2}{c|}{$\begin{array}{c}\text { Carotenoids } \\
\text { (mg/100f.w.) }\end{array}$} \\
\cline { 2 - 5 } & $\begin{array}{c}\mathbf{2 0 1 8} \\
\text { season }\end{array}$ & $\begin{array}{c}\mathbf{2 0 1 9} \\
\text { season }\end{array}$ & $\begin{array}{c}\mathbf{2 0 1 8} \\
\text { season }\end{array}$ & $\begin{array}{c}\mathbf{2 0 1 9} \\
\text { season }\end{array}$ \\
\hline Control & 0.10 & 0.30 & 0.03 & 0.25 \\
\hline Dry yeast at 2g/L & 0.08 & 0.35 & 0.09 & 0.40 \\
\hline Dry yeast at 4 g/L & 0.07 & 0.42 & 0.08 & 0.29 \\
\hline Urea at 0.5\% & 0.04 & 0.45 & 0.08 & 0.38 \\
\hline Urea at 1.0\% & 0.11 & 0.44 & 0.10 & 0.45 \\
\hline Urea at 1.5\% & 0.04 & 0.36 & 0.08 & 0.38 \\
\hline Urea at 2\% & 0.07 & 0.35 & 0.06 & 0.27 \\
\hline LSD (5 \%) & $\mathbf{0 . 0 1}$ & $\mathbf{0 . 0 2}$ & $\mathbf{0 . 0 1}$ & $\mathbf{0 . 0 4}$ \\
\hline
\end{tabular}


Respecting the role of urea as a source of nitrogen and dry yeast extract on leafy crops, Yildirim et al.(2007) stated that foliar spray with urea to plants during crop growth can improve the mineral status and increase nutrient in different tissues of these plants. Moreover, Taha et al. (2016) pointed out that the enhancement effect of yeast extract might be attributed to its influence on acting as a source of plant growth hormones and macro nutrients and vitamins which in turn increasing the chemical content of leaves.

Table (7): Effect of foliar spray with urea fertilizer levels and dry yeast extract on $\mathrm{N}, \mathrm{P}, \mathrm{K}$ and $\mathrm{NO}_{3}$

\begin{tabular}{|l|c|c|c|c|}
\hline \multirow{2}{*}{ Treatments } & \multicolumn{4}{|c|}{ Percentages } \\
\cline { 2 - 5 } & $\mathbf{N}$ & $\mathbf{P}$ & $\mathbf{K}$ & $\mathbf{N O}_{\mathbf{3}}$ \\
\hline Control & 1.52 & 0.22 & 1.24 & 0.045 \\
\hline Dry yeast at $2 \mathrm{~g} / \mathrm{L}$ & 2.68 & 0.23 & 2.23 & 0.029 \\
\hline Dry yeast at $4 \mathrm{~g} / \mathrm{L}$ & 2.82 & 0.25 & 2.37 & 0.027 \\
\hline Urea at $0.5 \%$ & 1.52 & 0.24 & 2.19 & 0.038 \\
\hline Urea at $1.0 \%$ & 2.88 & 0.26 & 2.41 & 0.025 \\
\hline Urea at 1.5\% & 2.63 & 0.26 & 2.21 & 0.040 \\
\hline Urea at 2\% & 2.24 & 0.22 & 1.25 & 0.038 \\
\hline LSD (5\%) & 0.01 & 0.03 & 0.02 & 0.014 \\
\hline
\end{tabular}

The present results resemble with those noticed by Yildirim et al. (2007), Wojciechowska and Kowalska (2011), Yucel et al. (2013), AbdelSalam (2018), and Ghimire et al. (2019), who sprayed plants with urea and improved that urea as foliar spray significantly increased the chemical content of plant leaves Moreover, Fawzy (2010 a), Shehata et al. (2012), Marzouk et al.(2014), Farrag et al. (2016), who spraying plant with yeast extract noticed that foliar spray of yeast significantly increased the chemical content of plant leaves.

Conclusively: it can be concluded that the treatment of $1 \%$ urea gave the best results on all characters of head lettuce.

\section{REFERENCES}

Abd El-Aal, Faten S., A. M. Shaheen, A. A. Ahmed and Mahmoud Asmaa R. (2010). Effect of foliar application of urea and amino acids 
mixtures as antioxidants on growth, yield and characteristics of squash. Res. J. Agric. and Bio. Sci., 6 (5) : 583 - 588.

Abdel - Salam, M. A. (2018). Response of lettuce (Lactuca sativa L.) to foliar spray using Nano-urea combined with mycorrhiza. J. Soil Sci. and Agric. Eng., Mansoura Univ., 9(10): $467-472$.

Abou El-Nasr, M.E., R.A. El-Shabrawy and M.M. Abd El-Rahman (2001). Effect of bread yeast application and some nutrient elements on squash (Cucurbita pepo L) plant growth, yield and fruit quality under conditions of the early summer planting. J. Agric. Sci. Mansoura Univ., 26(7): 4451-4464.

Ahmed, F.F., A.M. Aki, F.M. El-Morsy and M.A. Raggab,(1997). The beneficial effect of biofertilizer on red roomy grape vine (Vita vinfera L). the effect on growth and vine nutritional status. Annals of Agric. Sci, Moshtohor, 35(1): 489-495.

Alsaady, Majida H. M., H. A. Salim, A. K. Abdulrazzaq, U. N. Saleh, N. H. Jassim, A, R. Hamad, J. A. Attia, J.J. Darwish and A.F. Hassan (2020). Response of cabbage planst to foliar application of yeast suspension and nitrogen fertilizer. Eco. Env. \& Cons., 26 (2): 832 - 836.

Amer, S.S.A. (2004). Growth, green pods yield and seeds yield of common bean (Phaseolus vulgaris L) as affected by active dry yeast, salicylic acid and their interaction. J. Agric. Sci. Mansoura. Univ., 29(3): 1407-1422.

Broadley MR, AJ Escobar-Gutiérrez, A Burns, and IG Burns (2000). What are the effects of nitrogen deficiency on growth components of lettuce? New Phytologist, 147, 519-526

Chaudhury, B. (1967). Vegetables. National Book Trust: New Delhi, India.;195.

Edmeades, D.C. ( 2002). The effects of liquid fertilizers derived from natural products on crop, pasture, and animal production: A review. Australian Journal of Agricultural Research, 53: 965-976.

Edmond, J.B.; T.L Senn,.; F.S Znterw, and A.G.Hulfacre (1981). Fundamental of Horticulture. Tata Mc Graw. Hill. Publishing Co., Limited, India.

El-Sagan, M. A. M. (2015). Effect of some natural extracts on growth and productivity of cucumber under sandy soil conditions, Int. J. Adv. Res., 3(9): $677-686$.

El-Sherbeny, S. E. , M. Khalil, and M. S. Hussepn (2007).Growth and productivity of rue ( Ruts graveolens) under different foliar fertilizers application . J. Appli. Sci. Res., 3 ( 5) : 399-407. 
Farrag, D. K., O. A. Alaa El-Dein and I. F. Khafagy (2016). Impact of spraying with Saccharomces Cerevisiae and same commercial nutrients on lettuce plant (Lactuca sativa L.). productivity and prevention of some insect pests. Int. J. Plant \& Soil Sci., 11 (6): 1 -11.

Fathy, S.L. and S. Farid (2000). Effect of some chemical treatments, yeast preparationand Royal Jelly on some vegetable crops growing in late summer season toinduce their ability towards better thermal tolerance. J. of. Agric. Sci. Mansoura Univ., 25(4): 2215-2249.

Fawzy, Z. F. (2010a). Increasing productivity of head lettuce by foliar spraying of some bio and organic compounds. Mesopotamia J. Agric., $38(1): 1-9$.

Fawzy Z. F., El-Bassiony. A. M., Behairy, A. G.., and Y. I Helny. (2010b). Effect of foliar spraying by some bio and organic compounds on growth, yield and chemical composition of snap bean plants. Journal of Applied sciences Research, 6 (12): 2269-2274.

Fouda, F. and A. S. Abd-El hamied (2017). Influence of mineral fertilization rate and foliar application of yeast and ascorbic acid on yield, vegetative growth and fruits quality of eggplant .J. Soil Sci. and Agric. Eng., Mansoura Univ., Vol. 8(11): 643-648.

Ghimire, A. Nainabasti, M.D. Sarma, S. Marahatta, and H.N.Giri (2019).Effects of urea and poultry manure combination on yield and quality of different lettuce (Lactuca sativa L.) varieties in Chitwan, NEPAL. Saarc J. Agric., 17(1): 210 .

Guvenc, I., A. Karatas and A. Hckaymak (2006). Effect of foliar applications of urea, ethanol and putrecine on growth and yield of lettuce (Lactuca sativa). Indian Journal Of Agricultural Sciences, 76(1): 23-5.

Hakan Y., S. Sahin , S. Necdettin , M. Aydin , P.Cakmak, and N.Geboloğlu (2013).Foliar Applications of $\mathrm{Ca}, \mathrm{Zn}$ and urea on crispy lettuce in soilless culture. Soil- Water Journal, 2 (1) : 2146-7072.

Ivanova $\mathrm{V}$, and A Vassilev (2003). Biometric and physiological characteristics of Chrysanthemum (Chryanthemum indicum L.) plants grown at different rates of nitrogen fertilization. J. Cent.Europ. Agric. 4: 1-6.

Kanimarani, Sawsan M.S.A (2020). Effect of ashi star and yeast extract on vegetative growth characters of leafy lettuce (Lactuca sativa L.). Plant Archives, 20 (2): 1102 -1107. 
Kolotta, E. and M. Osinska (2001). Efficiency of foliar nutration of field vegetables grown at different nitrogen rates. In : Proc. Env. Probl. $N$ Fert. Acta Hort., $563: 87-91$.

Mahmoud E. Younis , N.A. M. Hasaneen, R. A.Adel and Dalia M.A. ElBialy (2008).Plant growth, metabolism and adaption relation lo stress conditions. XXl. Reversal of harmful Nacl-effects in lettuce foliar application with urea. Australian Journal of Crop Science, 2(2): 83-95.

Mahmoud, Asmaa R., M. El-Desuki, Mona M. Abdel-Mouty, and Aisha H.Ali, (2013). Effect of compost levels and yeast extract application on the pea plant growth, pod yield and quality, J. Appl. Sci. Res., 9 (1) : $149-155$.

Marzauk, Neama M., M. R. Shafeek, I. Helmy, A.A. Ahmed and Magda A. F. Shalaby, (2014). Effect of vitamin Eand yeast extract foliar application on growth, pod yield and both green pod and seed yield of brood bean (Vicia faba L.). Middle East J. Appl. Sci., 4 (1): 61- 67.

Masarirambi, M.T., P. Dlamini, P.K. Wahome and T.O. Oseni,( 2012). Effects of chicken manure on growth,yield and quality of lettuce (Lactuca sativa L.) 'Taina'under a lath house in a semi-arid sub tropical environment. American- Eurasian J. Agric. \& Environ. Sci., 12(3): 399-406.

Mona, M., S.M.A. Kabeel, and M.A. Fayza, ( 2005). Effect of organic and biofertilizer on growth, yield and fruit quality of cucumber grown under clear polyethelene low tunnels. J. Agric. Sci. Mansoura Univ., 30(5): 2827-2841.

Neama M. Marzauk, M. R.Shafeek, , Y. I. Helmy, A. A. Ahmed and Magda, A. F. Shalaby (2014).Effect of vitamin E and yeast extract foliar application on growth, pod yield and both green pod and seed yield of broad bean (Vicia Faba L.).Middle East journal of Applied Sciences, 4(1): 61-67.

Padem, H. and R. Alan(1995). The effect of foliar fertilizers on yield, chlorophyll and chemical content of lettuce (Lactuca sativa L.) Atatürk Univ. J. Agric. Fac., 26: 21-34.

Paradikovic, N., T. Vinkovic, I. VinkovicVrcek, I. ZuntarBojicm and M. Medic (2011). Effect of natural biostimulants on yield and nutritional quality: an example of sweet yellow pepper (Capsicum annuum L.) plants. Journal of Science and Food Agriculture. 91:2146-2152. 
Renata W. and L. Kowalska (2011). The effect of foliar application of urea, Mo and BA on nitrate metabolism in lettuce leaves in the spring and summer - autumn seasons. Folia Hort., 2312: 119-123.

Dol: 10. 2478/vol 245-011-0018-1

Rubatzky, V. E. and M. Tamaguchi (1997). World Vegetables, Principles, Production And Nutritive Values. Second edition, Chapman and hall International Thomson publishing . New Youk. USA. Pp.843.

Salama, A.R.O. (2019). Improving yield and quality of squash plants during winter season. M. Sc. Thesis, Fac. Technology and Development, Zagazig univ., PP 88.

Saleh, S. A., A.A. Glala, M. I. Ezzo and A.A. Ghoname (2010). An attempt for reducing mineral fertilization in lettuce production by using bio-organic farming system. Acta Hort., 852 : $311-318$.

SAS, (2004). Statistical Analysis System Institute, Cary NC, USA.

Sawsan Mohammed, and S. A.Kanimarani (2020). Effect of asahi star and yeast extract on vegetative growth characters of leafy lettuce (Lactuca sativa L.).Plant Archives Vol. 20, supplement 2, 2020 pp. 1102-1107 e. ISSN: 2581-6063 (online) ISSN: 0972-5210

Sharma, M.D. (2005). Jirisaag KoKheti. Krishi Sandesh. Post Graduate Student Society, IAAS.5-6: 4-7.

Shehata, S. A., Z., F. F. Fawazy and H. R. El-Ramady (2012). Response of cucumber plants to foliar application of chitosan and yeast greenhouse conditions. Australian J. Basic and Appl. Sci., 6 (4): 63-71.

Snedecor, G.W. and W.G. Cochran (1980). Statistical methods. 7th Edition, Ames: Iowa State University Press. USA. 480p.

Taha, L.S.; Ibrahim, S.M.M. and Abdel Aziz, N.G. (2016). Vegetative growth, chemical composition, and flavonoids content of Azadirachta indica plants as affected by application of yeast natural extract. Journal of Applied Pharmaceutical Science, 6(04): 093-097.

Vishwnath, R. P., R. Singh, N. Singh and Y. Kumar (2017). Effect of foliar application of nitrogen on growth and yield of vegetable pea (Pisum sativum L.) cv. Kashi Udai. J. Pharmacog. And Phytochem., 6 (5): $1500-1502$.

Wang, Z. H. , S. Li, and S. Malhi (2008). Effects of fertilization and other agronomic measures on nutritional quality of crops. J. Sci. Food Agr. , $88: 7-23$. 
Wojciechowska, R. (2004). Some aspects of nitrate metabolism in vegetables with special reference to butter head lettuce "Sprinter". Zesz. Nauk. A. R. W. Krakowie. Ser. Rozprawy: 297.

Wojciechowska, R. and I. Kowalska (2011). The effect of foliar application of urea, Mo and BA on nitrate metabolism in lettuce leaves in the spring and summer-autumn seasons. Folia Hort., 23 (2): 119 : 123.

Wojcik, P. (2004). Uptake of mineral nutrients from foliar fertilization. $J$. Fruit Orn. Plant Res. Spec. ed., 12: $201-218$.

Yildirim, E. I. Guvenc, M. Turan and A. Karatas (2007). Effect of foliar urea application on quality, growth, mineral uptake and yield of broccoli ( Brassica oleracea L. var. italica). Plant Soil Environ., 53 (3): $120-128$

Younis, M. E., N. A. H. Mohammed, A.R. Ahmed and Dalia M.A. ElBialy (2008). Plant growth, metabolism and adaptation in relation to stress conditions. XXI. Reversal of harmful Na Cl-effects in lettuce plants by foliar application with urea. Australian Journal of Crop Science, 2(2):83-95.

Yúcel, H., S. Şahin, N. Sağlam, M. Aydin, P. Cakmak and N. Geboloğlu (2013). Foliar applications of $\mathrm{Ca}, \mathrm{Zn}$ and urea on crispy lettuce in soilless culture. Soil-Water J., 2 (2): 23: 30.

Zakaria Fouad Fawzy (2010). Increasing productivity of head lettuce by foliar spraying of some bio and organic compounds .Mesopotamia J. of Agric. (ISSN1815-316x) Vol. (38) No. (Supplement 1).

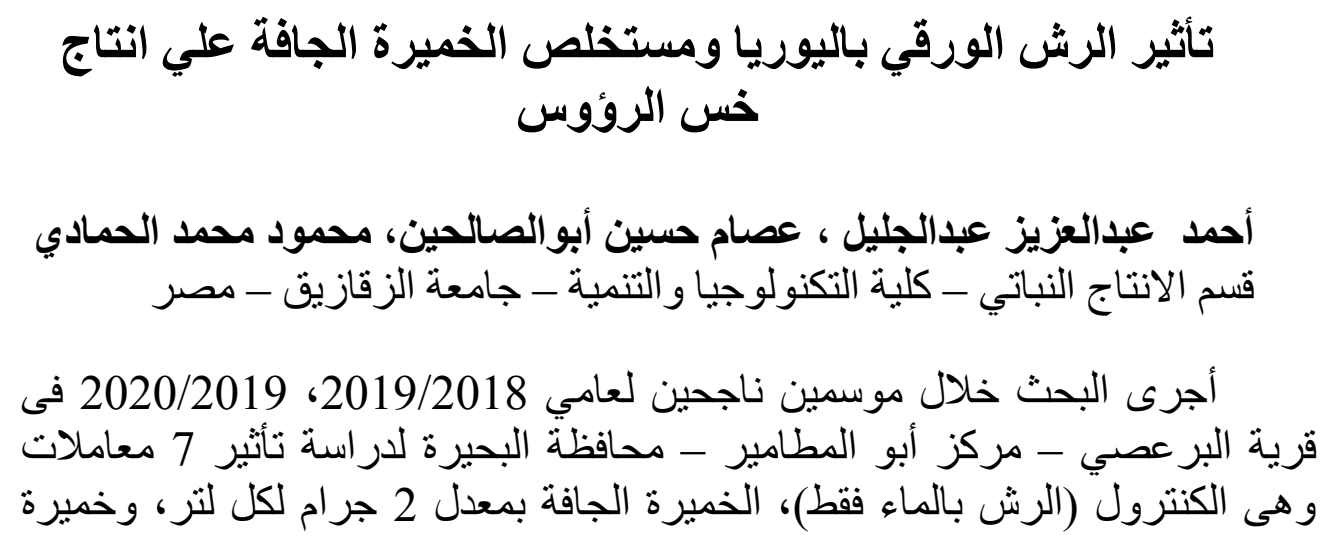


جافة 4 جر ام لكل لتر، واليوريا 0.5\% ويوريا 1\% و ويوريا 1.5\% ، يوريا 2\% على النمو و المحصول و المحتوى الكيماوي في الته نبات الخس.

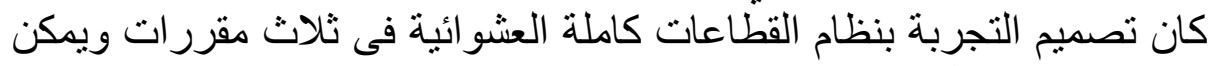

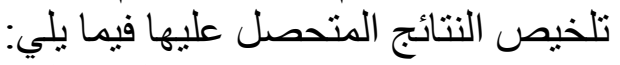

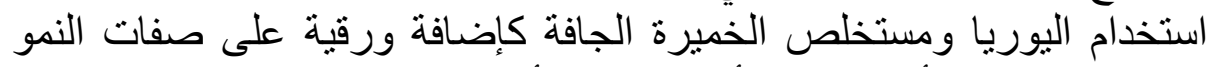

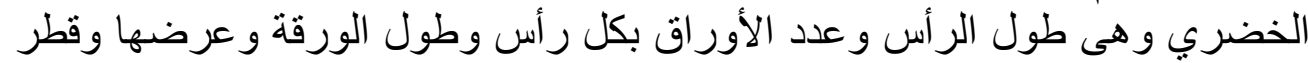

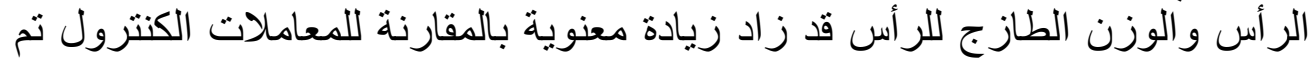

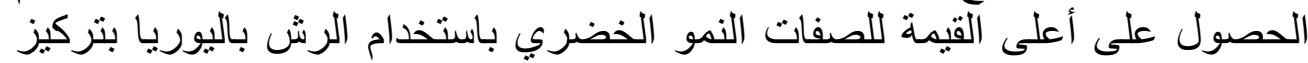

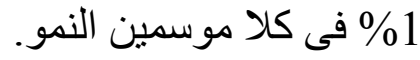

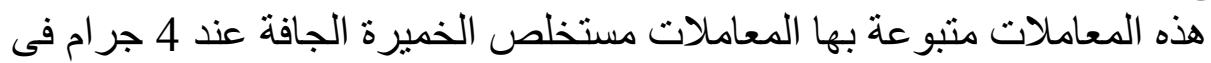
اللتر ومستخلص الخميرة الجافة بمعدل 2 جرام فى اللتر ومعدل 0.5 \% من اليوة اليوريا على التو الي المحتوى الصباغي.

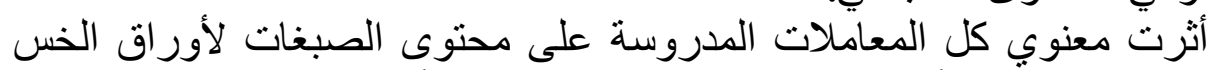

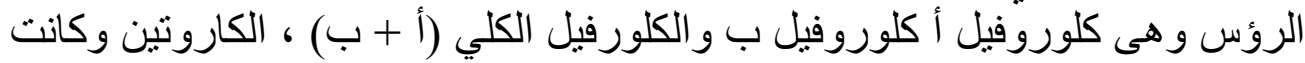

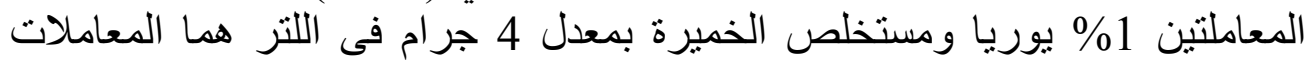
الأكثر فاعلية في قيمة المحتوى الصبني.

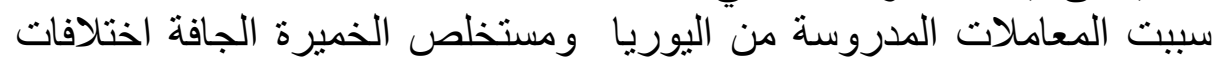
معنوية فى المحتوى الكيماوي من النتروجين و الفسفور و البوتاسيوم وتر التمثيرة النترات التيات

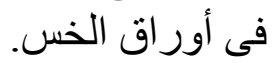
كان الرش الورقي باليوريا بمعدل 1\% قد قدل سل أعلى قيمة فى محتوى النتروجين

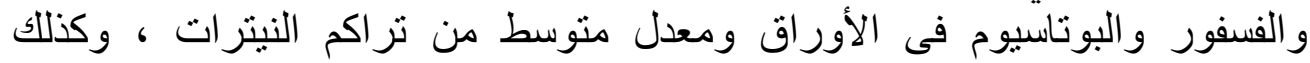

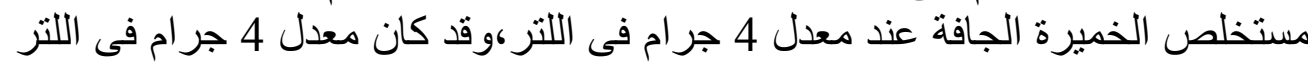

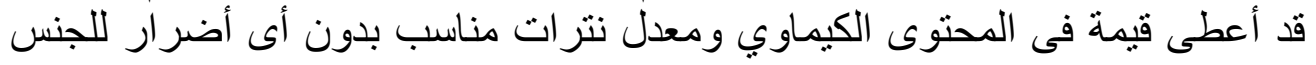

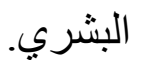

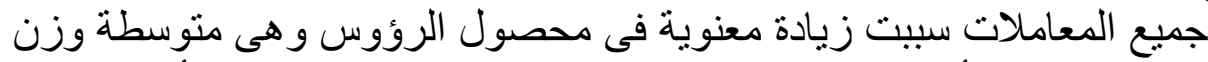

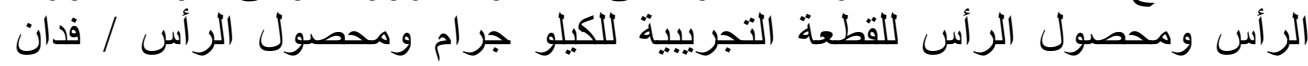

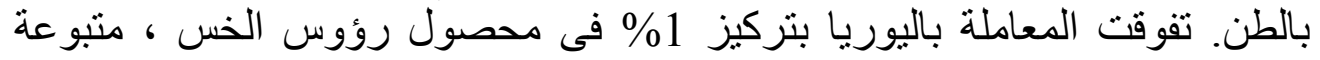

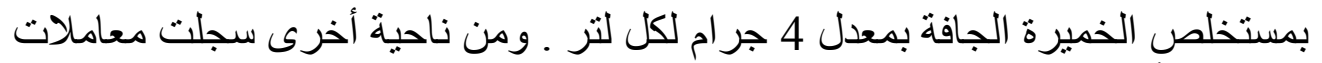

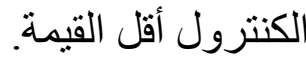
التوصية : يمكن أن نوصي بالرش باليوريا 1 \% و الخميرة الجافة بمعدل 4 جم / لتر

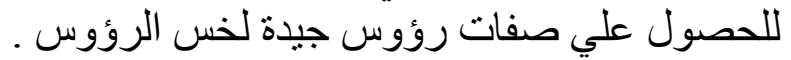

